\title{
De rol van modellen en methoden in produktontwikkeling
}

\author{
Dr. E.J. Nijssen, Drs. K.F.M. Lieshout en Dr. E. Peelen'
}

\section{Inleiding}

Het belang van nieuwe produkten voor bedrijven is groot en neemt toe (Gupta. 1994; Craig en Hart. 1992: Booz, Allen en Hamilton. 1982).

Bedrijven melden omzetaandelen tussen de 25 en 35 procent voor produkten die zij de afgelopen drie tot vijf jaar ontwikkelden (Urban en Hauser. 1993). Toch is het nieuw produktontwikkelingsproces voor veel ondernemingen nog slecht beheersbaar. Diverse onderzoeken zijn verricht naar het falen van nieuwe geïntroduceerde produkten. Faalpercentages liggen tussen de 20 en 46 procent (Urban en Hauser, 1993). Inzicht in de oorzaken voor het falen heeft vooral Cooper (1990) verschaft. De meeste redenen voor mislukkingen doen zich voor aan het begin en aan het eind van het ontwikkelingstraject. In de beginfase hebben ze onder andere betrekking op fouten in het onderkennen van de specifieke afnemerswensen, de ontwikkelingen in deze wensen alsmede de beoordeling c.q. inschatting van de concurrentie. In de commercialisatiefase gaat het om problemen bij het bepalen van het prijsniveau, de distributie en de verkoopondersteuning (zie Commandeur e.a.. 1993). Een algemeen genoemde faalfactor is verder de interne gerichtheid van de onderneming. Uil voorgatande analyse kom het belang van vergroting van de kans op succesvolle nieuwe produktintroducties naar voren. Behalve het tijdig signaleren van problemen is ook een vroeg inzicht in kansen welkom. In de tijd is een groot aantal modellen en methoden geïntroduceerd om het management te assisteren in deze taken (o.a. brainstormen, Quality Function Deployment, in-home-use-test). Exploratief onderzoek van Mahajan en Wind (1992) onder Amerikaanse Fortune 500-ondernemingen heeft evenwel aangetoond dat het gebruik van deze technieken beperkt is. Mogelijke redenen hiervoor zijn de geringe bekendheid van bedrijven met deze technieken, een organisatiecultuur die het gebruik ervan afremt, of slechte ervaringen (Feldman en Page. 1984). Nader inzicht in deze redenen is gewenst om verbeteringen te kunnen aanbrengen.

Het eerste gedeelte van dit artikel richt zich op de resultaten van een literatuurstudie. Een classificatieschema van de beschikbare modellen en methoden wordt gerapporteerd. In het tweede gedeelte worden de onderzoeksvragen gespecificeerd. De derde sectie beschrijft de onderzoeksmethode en het empirisch onderzoek. De vierde sectie bespreekt de resultaten. In het liatste deel worden de conclusies geformuleerd en bediscussieerd. Tot slot vindt een vergelijking plaats met de uitkomsten van de vergelijkbare Amerikaanse studie van Mahajan en Wind (1992) en worden aanbevelingen gedaan.

\section{De rol van modellen en methoden voor produktontwikkeling}

Talloze modellen en methoden zijn de afgelopen jaren ontwikkeld om het management te

Dr. E.J. Nijssen is verbonden aan de vakgroep Commerciële Beleidsvoering van de Erasmus Universiteit Rotterdam (EUR). Hij participeert in het Centrum voor marktgericht innoveren en het Centrum voor merken en merkenbeleid.

Drs. K.F.M. Lieshout studeerde bedrijfseconomie aan de EUR met als specialisatie industriële marketing. Sinds 1993 is zij werkzaam bij SKIM/INDIS Marktonderzoek als projectleider Dr. E. Peelen is parttime universitair hoofddocent bij de leerstoel Marktbeleid \& Marktonderzoek van de EUR. Tevens is hij partner bij ICSR, Adviesbureau voor marketing en strategie. Hij participeert in het Centrum voor marktgericht innoveren 
ondersteunen bij de ontwikkeling en introductie van nieuwe produkten. In 1976 trof Schelker er al meer dan 600) aan. Zij zijn in het algemeen gericht op het systematisch identificeren van problemen en het vergroten van de succeskans door specifiek inzicht te verschaffen in de markt- en ondernemingskansen. De technieken zullen we classificeren aan de hand van vier, voor produktontwikeling, fundamentele vragen (Oppedijk van Veen. 1987). Deze vragen zijn:

1 Welk produkı moeten worden ontworpen?

2 Hoe dient het produkt ontworpen te worden?

3 Hoe dient het produkt op de markı geïntroduceerd te worden?

4 Wat is de verwachte slaagkans voor het nieuwe produkt?

De gemaakte classifïcatie van modellen en methoden staat weergegeven in figuur 1. Overigens zijn alleen de meest geciteerde modellen en melhoden in de classificatie opgenomen. De indeling correspondeert met de vier probleemfasen in het ontwikkelingsproces van nieuwe produkten. te weten de ideegeneratie. de produktoptimalisatie. de optimalisatie van de marketing mix en de voorspelling van de kans op succes.

figuar 1: Classificatic van modellen en methoden boor produktontwikkeling

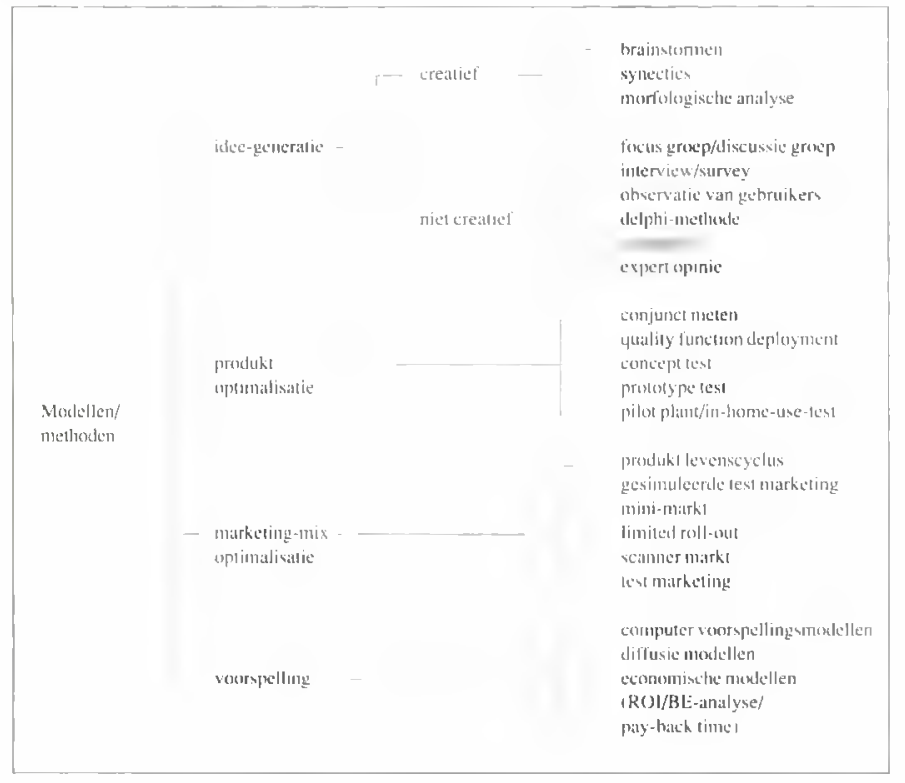

Hoewel er veel is geschreven over de technieken zelf (wat is het en hoe een en ander "normatief" toe te passen), is het aantal publikaties over het leitelijke gebruik gering (Mahajan en Wind, 1992; Buijs, 1984: Holt. 1987). Van laatstge- noemde publikaties gaan de meeste over de ideegeneratiefase. Geschka $(1983,1978)$ heeft in de periode 1973-1980 de penetratie onderzocht van verschillende creativiteit-stimulerende methoden in Duitsland. Hij kwam tot de conclusie dat de bekendheid met methoden zoals brainstormen, morlologische analyse en synectics in de onderzoekperiode wel sterk was gestegen, mair dat het gebruik toch altijd nog op een laag niveau was gebleven. Veel verbetering verwachtte hij niet. Verhage e.a. (1981) hebben zich ook op de ideegeneratiefase gericht. In hun kwalitatief onderzoek onder negen Nederlandse ondernemingen trolfen zij een laag gebruiksniveau aan van geformaliseerde modellen en methoden om nieuwe ideeën systematisch te genereren. Het gebruik werd belemmerd door een wantrouwen in de effectiviteit van de technieken, ongeacht of het management er wel of niet bekend mee was.

Mel betrekking tot modellen en methoden voor produktoptimalisatie is onder andere onderzock verricht door Griflin (1992). Zij richtte zich specifiek op Quality Function Deployment (QFD). QFD is een nieuw ontwikkelde techniek die een brug probeert te slaan tussen afnemerswensen en produktenginecring. Rond 1987 was het antal gebruikers in de Verenigde Staten naar schalting 24. Voor conjunct meten, een andere nicuwe en minder complexe produktoptimaliseringsmethode. lag het aantal toepassingen/gebruikers begin jaren tachtig al op circa 200 tot 400 (Wittink en Cattin. 1989). Een verdere groei werd verwacht.

Afgezien van de hiervoor genoemde onderzoeken die zich richten op cen specifieke techniek, zijn er slechts twee onderzoeken die het gebruik van de modellen en methoden voor nieuw-produktontwikkeling in een breder perspectief platsen. Schelker (1976) heeft de toepassing van een aantal technieken onderzocht onder 90 kleine en grotere ondernemingen in Zwitserland. Hij heelt zich gericht op methoden voor analyse, voorspelling. ideegeneratic, selectie en planning/beheersing. Hij trof een redelijke penetratiegralad en satisfactieniveau aum bij de onderzochte managers. Een bepaalde positieve bijdrage aan het produktontwikkelingsproces werd bovendien gemeld. Recentelijk hebben Mahajan en Wind (1992) in de Verenigde Staten onderzoek gedaan naar het gebruik van modellen en methoden. Onder Fortune 500 -ondernemingen troffen zij een lage penetratie 
aan alsmede een weinig, op specifieke problemen en ontwikkelfasen gericht gebruik. De tevredenheid met de technieken was evenwel goed.

\section{Onderzoeksvragen}

Als we de uitkomsten van de recente studie van Mahajan en Wind (1992) vergelijken met die van de studies uit het midden van de jaren zeventig dan zien we dat het gebruik van de modellen en methoden niet is gestegen. Ondanks dat de metingen in verschillende geografische gebieden zijn verricht en onder ondernemingen van verschillende grootte, zou dit erop kunnen wijzen dat ondernemingen de technieken reeds hebben 'afgedankt'. Soortgelijke verschijnselen hebben zich ook voorgedaan bij bijvoorbeeld BCG-modellen en PIMS (McCabe en Naraganan, 1991). Het organisatieklimaat, waarop Verhage e.a. (1981) hebben gewezen, kan ook de groei belemmerd hebben.

Om nader inzicht te vergaren in de bekendheid met, het gebruik en de effectiviteit van de modellen en methoden voor de ontwikkeling van nieuwe produkten, zijn vijf onderzoeksvragen geformuleerd:

1 In welke mate zijn ondernemingen bekend met het bestaan van modellen en methoden voor de ontwikkeling van nieuwe produkten?

2 In welke mate worden zij gebruikt?

3 Gedurende welke fasen van het produktontwikkelingsproces worden zij gebruikt?

4 Waarom wordt er gebruik van gemaakt?

5 In welke mate zijn ondernemingen tevreden met de modellen en methoden en wat zijn hun belangrijkste tekortkomingen?

\section{Onderzoek}

Om bovenstaande onderzoeksvragen te beantwoorden, werd eerst kwalitatief onderzoek verricht. Het doel was meer inzicht te verwerven in produktontwikkeling binnen Nederland in het algemeen en in het gebruik van ondersteunende technieken in het bijzonder. Drie expert-interviews werden gehouden met stafmedewerkers van de Technische Universiteit Delft. Ook werd een groepsdiscussie georganiseerd. Dit laatste gebeurde in samenwerking met de industriële marketing groepering van het NIMA. De zeven participanten aan de discussie zijn/waren als manager of consultant betrokken bij produktontwikkelingspro- cessen. De 'input' voor het kwalitatief onderzoek vormde de vragenlijst die werd gebruikt door Mahajan en Wind (1992).

Een belangrijke uitkomst van het kwalitatieve onderzoek was, dat het produktontwikkelingsproces van consumentenprodukten anders verloopt dan dat van industriële goederen. In industriële markten is de betrokkenheid van afnemers bij het ontwikkelingsproces groter; het neemt zelfs de vorm aan van 'participeren in'. In de fasering van het proces kunnen zich tussen consumenten- en industriële markten - en zelfs daarbinnen - eveneens verschillen voordoen. Tot slot bleek in dit vooronderzoek dat respondenten vaak wel bekend zijn met een model of methode, maar deze niet bij naam kennen. Soms is een methode of model ook onder een andere naam door een advies- of marktonderzoeksbureau geïntroduceerd.

Vervolgens werd kwantitatief onderzoek verricht. Er werd besloten dit toe te spitsen op ondernemingen die in business-to-businessmarkten opereren. Deze afbakening werd ingegeven door de beperkte beschikbaarheid van literatuur over produktontwikkeling in business-tobusiness-markten (Moore, 1987) en de noodzaak consumenten en industriële produktontwikkeling te scheiden. Er werd gebruik gemaakt van een quotum-steekproef van 75 ondernemingen. De bedrijven werden geselecteerd uit het ABCregister. De steekproef omvatte bedrijven uit de elektronica-industrie, machinebouw, metaal- en papierindustrie. De benaderde respondenten waren werkzaam op het gebied van de produktontwikkeling in de functie van marketing manager, newbusiness manager, R\&D manager en dergelijke. Van de benaderde respondenten reageerde $60 \%$ positief. Voornamelijk marketing managers hebben meegewerkt (70\%). De ondernemingsgrootte varieerde; de mediaan lag bij een omvang van 200-500 werknemers.

Telefonische interviews zijn gehouden om de data te verzamelen. De opbouw van het vraaggesprek was zodanig dat eerst naar de bekendheid met de modellen en methoden werd gevraagd, alvorens daarop een nadere toelichting te geven. Er werden geen aanwijzingen gevonden dat respondenten een positiever beeld van de bekendheid met, het gebruik van, en de tevredenheid met de modellen en methoden verschaften om professioneler over te komen. 
Om de duur van de vraaggesprekken te beperken concentreerde het onderzoek zich op elf modellen en methoden (zie bijlage). De keuze viel op modellen en methoden waarvan in het kwalitatief vooronderzoek en eerder empirisch onderzoek bleek dat zij enige bekendheid genieten. Vraagvoorspellingsmodellen werden daarom niet meegenomen (zie Mahajan en Wind, 1992). Voorts spitste het onderzoek zich toe op 'new-tothe-world-products', nieuwe produktlijnen en toevoegingen aan huidige produktlijnen. Modellen en methoden kunnen volgens Mahajan en Wind (1992) met name voor deze categorie produkten een substantiële bijdrage leveren.

De variabelen werden als volgt geoperationaliseerd. De naamsbekendheid en de inhoudelijke bekendheid met de modellen en methoden werden gemeten met binominale schalen ( $\mathrm{ja} /$ nee). De mate waarin er gebruik van wordt gemaakt, is gemeten met behulp van een driepuntsschaal (soms/verschillende keren/altijd). In het geval de techniek niet werd gebruikt, werd vastgesteld of deze in het verleden wel was gebruikt ( $\mathrm{ja} / \mathrm{nee}$, inclusief specificatie begin- en eindjaar).

Voor de redenen van toepassing werd teruggevallen op een lijst met motieven die werd ontleend aan voorgaande onderzoeken (o.a. Mahajan en Wind, 1992: Schelker, 1976). De tevredenheid werd op een driepuntsschaal gemeten (hoog/middel/laag). Om nader inzicht te verkrijgen in de wijze waarop het ontwikkelingsproces van nieuwe produkten is georganiseerd, zijn vragen gesteld over onder andere de mate waarin ontwikkelfasen in het algemeen worden doorlopen.

\section{Resultaten}

\section{a De bekendheid met de modellen en methoden}

Zoals te verwachten, doen zich grote verschillen voor in naams- en inhoudelijke bekendheid met de modellen en methoden (zie tabel 1). De gemiddelde bekendheid is $30 \%$. Na het geven van een toelichting loopt de bekendheid op tot $57 \%$, hetgeen bijna een verdubbeling betekent. Zes van de elf onderzochte modellen en methoden hebben
Tabel 1: Bekendheid met de modellen en methoden

\begin{tabular}{|c|c|c|}
\hline & $\begin{array}{l}\text { \% Respondenten dat } \\
\text { kent na omschrijing }\end{array}$ & $\begin{array}{l}\text { \% Respondenten dat } \\
\text { kent op basts tan naam }\end{array}$ \\
\hline Brainstomen & $97 \%$ & $96 \%$ \\
\hline Concept-test & $88 \%$ & $29 \%$ \\
\hline In-home-usc-tes! & $82 \%$ & $51 \%$ \\
\hline PLC & $81 \%$ & $65 \%$ \\
\hline Focus-groep & $71 \%$ & $6.3 \%$ \\
\hline Mortologische analyse & $54 \%$ & $14 \%$ \\
\hline Conjunct meten & $51 \%$ & $4 \%$ \\
\hline QFD & $32 \%$ & $7 \%$ \\
\hline Limited-roll-sut & $29 \%$ & $3 \%$ \\
\hline Synoctics & $28 \%$ & $6 \%$ \\
\hline Delphi-methorle & $18 \%$ & $0 \%$ \\
\hline Gemiddelde & $57 \%$ & $30 \%$ \\
\hline
\end{tabular}

een zeer lage bekendheid (minder dan 15\%). Drie technieken scoren zelfs onder de $30 \%$ nadat een toelichting is gegeven. Het gaat om de Delphimethode, de limited roll-out en synectics. Het meest bekend zijn brainstormen, focus-/discussiegroep, produkt-levenscyclus en de in-home-usetest. Zij hebben een bekendheid van boven de $80 \%$.

\section{b Gebruik van de modellen en methoden}

Tabel 2 geeft aan in welke mate de ondernemingen uit het onderzoek de onderscheiden modellen en methoden gebruiken. Het gemiddeld penetratieniveau is $30 \%$. Dat is ongeveer de helft van de ondernemingen die, na toelichting, zegt bekend te zijn met het model of de methode. Het meest toegepast worden brainstormen, concepttest en in-home-use-test. Het minst gebruikt worden de Delphi-methode en synectics met scores onder de $10 \%$.

Rekening houdend met de nieuwheid van QFD en conjunct meten zijn de voor deze methoden aangetroffen resultaten bemoedigend. Ter aanvulling op de tabel valt verder te melden dat bijna $60 \%$ van alle respondenten minstens één

Tabel 2: Gebruik en ex-gebruik modellen en methoden (\% van alle respondenten)

\begin{tabular}{|l|c|c|}
\hline & Gebruik & Ex-gebruik \\
\hline Brainstomen & $61 \%$ & $9 \%$ \\
Concept-test & $61 \%$ & $1 \%$ \\
In-home-usc-test & $60 \%$ & $0 \%$ \\
PLC & $39 \%$ & $3 \%$ \\
Focusgroep & $38 \%$ & $1 \%$ \\
Moriologische analyse & $29 \%$ & $1 \%$ \\
Conpunct meten & $17 \%$ & $0 \%$ \\
QFD & $17 \%$ & $1 \%$ \\
Limited-roll-out & $17 \%$ & $0 \%$ \\
Synectics & $10 \%$ & $0 \%$ \\
Delphi-methode & $6 \%$ & $0 \%$ \\
Gemiddclde & $\ldots \% \%$ & $2 \%$ \\
\hline
\end{tabular}


model of methode gebruikt. Voorts blijkt het aantal respondenten dat gestopt is met het gebruik van de onderzochte modellen en methoden klein (zie tabel 2).

c Gebruik van modellen en methoden per fase van het produktontwikkelingsproces

De meeste modellen en methoden richten zich op bepaalde specifieke problemen die spelen tijdens bepaalde fasen van het produktontwikkelingsproces. Zonder in detail te willen treden, kunnen wij melden dat het gebruik zich echter juist in de praktijk over meer fasen uitstrekt. De inzet beperkt zich niet tot díe momenten waarvoor de technieken oorspronkelijk bedoeld zijn.

Dit geldt in het bijzonder voor QFD en alle ideegeneratiemethoden. Met uitzondering voor de limited-roll-out worden alle technieken in meer dan $25 \%$ van de gevallen ingezet in fasen waarvoor zij níet ontwikkeld zijn. Van een gerichte inzet van de technieken is zodoende geen sprake!
Tevens blijkt dat in de fasen marketingstrategie, economische analyse en commercialisatie relatief weinig van modellen en methoden gebruik wordt gemaakt.

\section{d Gebruiksredenen}

De belangrijkste gebruiksreden voor tien van de elf modellen en methoden is het identificeren van problemen (zie tabel 3). In de ideegeneratiefase is de daaropvolgende reden de vergroting van de succeskans van een nieuw produkt. Verderop in het ontwikkelingstraject doet zich een verschuiving voor. Het tweede meest belangrijke motief in de produktoptimalisatie en de marketing-mixoptimalisatiefase is de ondersteuning van het verkoopapparaat.

\section{e Mate van tevredenheid met de modellen en methoden en tekortkomingen}

De tevredenheid met de modellen en technieken is goed (zie tabel 3 ). Het lage percentage klachten onderstreept dit. Wel moeten we voorzichtig zijn

Tabel 3: Mate van tevredenheid, redenen voor gebruik en tekortkomingen van de modellen en methoden

\begin{tabular}{|c|c|c|c|c|c|c|c|c|c|}
\hline & \multirow[b]{2}{*}{ Methode } & \multirow[b]{2}{*}{$\begin{array}{l}\text { Aantal } \\
\text { respondenten }\end{array}$} & \multicolumn{3}{|c|}{ Mate van tevredenheid } & \multirow{2}{*}{$\begin{array}{l}\text { Redenen gebruik } \\
\text { reden }\end{array}$} & \multicolumn{3}{|c|}{ Belangrijkste tekortkomingen } \\
\hline & & & $\begin{array}{l}\text { Hoog } \\
\%\end{array}$ & $\begin{array}{l}\text { Midden } \\
\%\end{array}$ & $\begin{array}{l}\text { Laag } \\
\%\end{array}$ & & $\%$ & Tekort & $\%$ \\
\hline \multirow{5}{*}{$\begin{array}{l}\text { idee } \\
\text { gene- } \\
\text { ratie }\end{array}$} & Brainstonnen & 44 & 81 & 11 & 5 & $\begin{array}{l}\text { Identificatie problemen } \\
\text { Verbeleren success rate }\end{array}$ & $\begin{array}{l}52 \\
41\end{array}$ & Te veel tijd & 27 \\
\hline & Synectics & 7 & 72 & 29 & 0 & Identificatie problemen & 43 & Te veel tijd & 29 \\
\hline & Morfologische analyse & 21 & 86 & 10 & 5 & $\begin{array}{l}\text { Identificatie problemen } \\
\text { Verbeteren success rate }\end{array}$ & $\begin{array}{l}86 \\
48\end{array}$ & Te veel tijd & 24 \\
\hline & Focusgrnep & 27 & 89 & 4 & 7 & Identificatie problemen & 67 & Onnauwkeurige voorspelling & 26 \\
\hline & Delphi-methode & 4 & 75 & 25 & 0 & $\begin{array}{l}\text { Identificatie problemen } \\
\text { Ondersteunen verkoopapparaat }\end{array}$ & $\begin{array}{l}50 \\
25\end{array}$ & $\begin{array}{l}\text { Te veel tijd } \\
\text { Markt te complex } \\
\text { om in model te vangen }\end{array}$ & $\begin{array}{l}25 \\
25\end{array}$ \\
\hline \multirow{5}{*}{$\begin{array}{l}\text { produkt- } \\
\text { optima- } \\
\text { lisatie }\end{array}$} & Produkt- levenscyclus & 28 & 79 & 21 & 0 & $\begin{array}{l}\text { Identificatie problemen } \\
\text { Verbeteren success rate }\end{array}$ & $\begin{array}{l}39 \\
25\end{array}$ & $\begin{array}{l}\text { Markl te complex } \\
\text { om in model te vangen }\end{array}$ & 21 \\
\hline & Conjunct meten & 12 & 75 & 17 & 0 & $\begin{array}{l}\text { Verbeteren success rate } \\
\text { Ondersteunen verkoopapparaat }\end{array}$ & $\begin{array}{l}83 \\
58\end{array}$ & $\begin{array}{l}\text { Onnauwkeurige voorspelling } \\
\text { Te veel tijd }\end{array}$ & $\begin{array}{l}25 \\
25\end{array}$ \\
\hline & QFD & 12 & 92 & 0 & 0 & $\begin{array}{l}\text { Identificatie problemen } \\
\text { Verbeteren success rate }\end{array}$ & $\begin{array}{l}83 \\
75\end{array}$ & $\begin{array}{l}\text { Te gecompliceerd } \\
\text { Te veel tijd }\end{array}$ & $\begin{array}{l}17 \\
17\end{array}$ \\
\hline & Concept-1est & 44 & 75 & 23 & 2 & $\begin{array}{l}\text { Identificatie problemen } \\
\text { Ondersteunen verkoopapparaat }\end{array}$ & $\begin{array}{l}55 \\
43\end{array}$ & Te veel tijd & 18 \\
\hline & In-home-use-test & 43 & 77 & 14 & 5 & $\begin{array}{l}\text { Identificatie problemen } \\
\text { Ondersteunen verkoopapparaat }\end{array}$ & $\begin{array}{l}58 \\
35\end{array}$ & Te veel tijd & 33 \\
\hline $\begin{array}{l}\text { m.mix- } \\
\text { optima- } \\
\text { lisatie }\end{array}$ & Limited-roll-out & 12 & 67 & 33 & 0 & $\begin{array}{l}\text { Identificatie problemen } \\
\text { Ondersteunen verkoopapparaat }\end{array}$ & $\begin{array}{l}47 \\
33\end{array}$ & Te veel tijd & 42 \\
\hline
\end{tabular}


met generaliseren. Het aantal waarnemingen per gebruikte techniek is immers klein. Toch valt op dut met name de gebruikers van QFD, focusgroep en morfologische analyse content zijn.

De belangrijkste tekortkomingen van de technieken houden verband met de tijd die gemoeid is met hun implementatie. Daarnaast wordt kritiek geuit op het voorspellend vermogen. Ook ervaart men problemen met het 'vangen' van de complexiteit van de markt binnen de modellen.

\section{Conclusies en aanbevelingen}

Uit de resultaten blijkı dat de bekendheid van de modellen en methoden op het gebied van de produkiontwikkeling sterk uiteenloopt. De naamsbekendheid is voor de onderzochte technieken gemiddeld $30 \%$. De inhoudelijke bekendheid ligt echter beduidend hoger, namelijk op 57\%. Van degenen die bekend zijn met de modellen en methoden past de helft ze daadwerkelijk toe. Hel penetratiepercentage komt daarmee uit op 30\%. Het meest toegepast worden brainstormen, concept-test en in-homeuse-test.

Het 'overall' penetratiepercentage komt sterk overeen met de uitkomsten van het onderzoek van Mahajan en Wind ( 1992) voor Amerikaanse ondernemingen. Per techniek zijn er echter grote verschillen (zie tabel 4). Nederlandse ondernemingen maken meer gebruik van de produktlevenscyclus (PLC) en concept testen dan hun Amerikaanse collega's. Andersom maken de Amerikanen meer gebruik van focusgroepen en limited-roll-out.

Deze verschillen kunnen echter volledig verklaard worden vanuit de verschillende type bedrijven in beide steek proeven. Het onderzoek van Mahajan en Wind richtte zich op Fortune 500 ondernemingen actief in consumenten-, diensten- en/of business-to-business-markten. Wij bestudeerden daarentegen specifiek middelgrote bedrijven in business-to-business-markten. Andere empirische onderzoeken hebben aangetoond dat grote ondernemingen waarschijnlijk het PLC-concept al hebben verlaten. Verder zijn focus-groep en limited-roll-oul meer van toepassing op consumenten- dan industriële markten, waar men doorgaans maar met een beperkt aantal afnemers te maken heeft.
Tabel 4: Cross-cultureel vergelijk: percentage gebruik modellen en methoden

\begin{tabular}{|c|c|c|}
\hline Merhode & $\begin{array}{l}\text { Nederland } \\
\quad(\mathrm{n}=7.5)\end{array}$ & $\begin{array}{l}\text { I.S. (Mahajan an Wind, 1992) } \\
\qquad(\mathrm{n}=78)\end{array}$ \\
\hline $\begin{array}{l}\text { PLC } \\
\text { Morfologische unalyse } \\
\text { Synectics } \\
\text { Delpli-methode } \\
\text { Concept-test } \\
\text { Focusgroep } \\
\text { Conjunct meten } \\
\text { QFD } \\
\text { I imited-roll-oul }\end{array}$ & $\begin{array}{l}31 \% \\
3 \% \\
4 \% \\
0 \% \\
57 \% \\
3.3 \% \\
1 \% \\
4 \% \\
1 \%\end{array}$ & $\begin{array}{r}8 \% \\
<5 \% \\
8 \% \\
9 \% \\
26 \% \\
68 \% \\
15 \% \\
9 \% \\
42 \%\end{array}$ \\
\hline \multicolumn{3}{|c|}{ 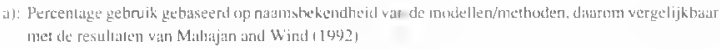 } \\
\hline
\end{tabular}

Net als Mahajan en Wind (1992) vinden wij verder een relatief diffuse inzet van de modellen en methoden. De modellen en methoden worden ingezet gedurende verschillende fasen van het produktontwikkelingsproces. Zij worden zelfs gebruikt in fasen waarvoor zij niet bestemd zijn/ lijken. De toepassing vindt blijkbaar meer praktisch en creatief plaats en minder formeel. De respondenten zien waarschijnlijk het produktontwikkelingsproces als een continu, cyclisch proces in plaats van als een sequentiële lijn van activiteiten. Het gegeven dat een groot deel van de respondenten de modellen/methoden niet bij natam kent kan erop duiden dat zij de technieken zelf hebben (her)ontdekt.

Opmerkelijk is dat zeer weinig modellen en methoden worden gehanteerd gedurende de fasen waarin de marketingstrategie, de economische analyse en de commercialisatie centraal staan.

Dit zijn juist de fasen waarin (volgens de literatuur) de meeste oorzaken voor het falen van nieuwe produkten te vinden zijn. Redenen voor de lage penetratie kunnen de beperking van het aantal technieken in het onderzoek en de ondergeschikte rol van marketing in industriële markten zijn (Workman, 1993). Moore (1987) en Cooper en Kleinschmidt (1986) stellen namelijk dat $87 \%$ van de industriële ondernemingen wel enige vorm van marktonderzoek laat voorafgaan aan introductie, maar dat slechts $20 \%$ grootschalig kwantitatief onderzoek verricht.

De belangrijkste reden voor het gebruik van de modellen en methoden is het identificeren van problemen. Een uitzondering moet gemaakt worden voor conjunct meten, dat vooral wordt toegepast om de succeskans van nieuwe produkten te vergroten. De op een na belangrijkste 
gebruiksreden verschuift gedurende de fasen van het ontwikkelingsproces. In het begin staat dan de succeskans van een nieuw produkı centraal, later gait het om het ondersteunen van het verkoopapparat bij de commercialisatie.

De belangrijkste tekortkomingen van de modellen en methoden houden verband met de eerder genoemde tijdbelasting, de beperkte voorspelkracht en de te sterke simplificaties die erin worden aangebracht. Dit laatste geldt in het bijzonder voor de focusgroep. conjunct meten en de produkt-levenscyclus. Deze resultaten zijn in overeenstemming met die van Mahajan en Wind (1992). De tevredenheid met de modellen en methoden is evenwel zeer goed. Het aantal exgebruikers is laag en het percentage respondenten dat tekortkomingen meldt, is beperkt. Alhoewel subjectiviteit deze uitkomsten positief beïnvloedt ('we gebruiken het, dus...'), zijn deze bevindingen in overeenstemming met eerder gevonden resultaten (Mahajan en Wind, 1992). Bovendien hebben Nijssen en Lieshout (1995) recentelijk een positief verband tussen de mate van gebruik van modellen/methoden en financiële bedrijfsprestatie angetoond.

Gegeven het voorgaande zijn de volgende conclusies met betrekking tot het gebruik van modellen en methoden voor nieuw-produktontwikkeling te trekken. Bedrijven lijken te profiteren van het gebruik van modellen en methoden binnen het nieuw-produktontwikkelingsproces. Toepassing lijkt de succeskans van nieuwe produkten te verbeteren. Verder helpen de technieken het ontwikkelproces te structureren en vergemakkelijken zij waarschijnlijk de communicatie door het blootleggen van problemen en het maken van inschattingen ten aanzien van slaagkansen.

Specifieke kwaliteitsverbeteringen van de technieken zelf lijken niet direct nodig, hoewel iedere techniek zijn eigen beperkingen heeft. Gegeven de beperkte penetratiegraad van het gebruik van de modellen en methoden verdient het aanbeveling de naams-en inhoudelijke bekendheid van diverse technieken te vergroten. Het gebruik zal gestimuleerd dienen te worden door bijvoorbeeld universiteiten en bedrijfsadviseurs. Hierbij moet met name ook op een juiste inzet worden gewezen. Hoewel nader onderzoek nodig is. lijkt het dat met name technieken die kunnen worden ingezet in de fasen na de produk- toptimalisatie, aandacht verdienen. Veel van de faaloorzaken zijn in deze fasen te vinden. De kans op meer succes en minder verspilling van ontwikkelingsbudgetten, zal dan ook kunnen komen van de toepassing van modellen en methoden als (simulated) test marketing en het gebruik maken van 'lead users'.

Vanzelfsprekend zal aan de ontwikkeling van nieuwe en betere modellen en methoden gewerkt moeten blijven worden (Sanchez en Sudharshan, 1993). Juist door kortere produktlevenscycli. nieuwe technologieën e.d. worden ook de eisen die aan modellen en methoden gesteld worden steeds hoger.

\section{I T E R A T U U R}

Booz, Allen \& Hamilton, (1982), "New products management for the 1980s", Booz, Allen \& Hamilton Inc., New York.

Buils, J., (1984), "Innovatie en interventie", 2nd edition, Deventer: Kluwer.

Commandeur, H.R., R.D. Menko en E. Peelen, (1993), "Marktgericht innoveren", Stenfert Kroese, Leiden

Cooper, R.G., (1990), "New Products: What distinguishes the winners?", Research Technology Management, NovemberDecember, pp. 27-31.

Cooper, R G. en E.J. Kleinschmidt, (1986), "An investigation into the new product process: steps, deficiencies and impact", Journal of Product Innovation Management, No. 3, pp. 71-85.

Craig, A. en S. Hart, (1992), "Where to now in the new product development research?", European Journal of Marketing, Vol. 26, No. 11, pp. 3-49

Feldman, L.P. en Page A.L., (1984), "Principles vs. Practice in New Product Planning", Journal of Product Innovation Management, Vol. 1, pp. 43-55.

Geschka, H., (1978), "Introduction and use of idea generating methods", Research Management, May, pp. 25-28.

Geschka, H., (1983), "Creativity techniques in product planning and development: A view from West Cermany", R\&D Management, Vol. 13, No. 3, pp. 169-183.

Griffin, A., (1993), "Measering product development time to improve the development process", Marketing Science Institute Working Paper, Report number 93-118, October. Gupta, A.K., (1994), "Changing Patterns in Industrial R\&D Management", working paper, gepresenteerd op lezingen cyclus Centrum voor Marktgericht Innoveren, Erasmus Universiteit, Rotterdam.

Holt, K., (1987), "Product innovation management: a workbook for management in industry", London: Butterworths. 
Mahajan, V. and J. Wind, (1992), "New product models, practice, shortcomings and desired improvements", Journal of Product Innovation Management, No. 9, pp. 128-139.

McCabe, D.L. en V.K. Narayanan, (1991), "The life cycle of the PIMS and BCG models", Industrial Marketing Management, No. 20, pp. 347-352.

Moore, W.L., (1987), "New Product Development Practices of Industrial Marketeers", Journal of Product Innovation Management, Vol. 4, pp. 6-20.

Nijssen, E. en K. Lieshout, "Awareness, use and effectiveness of models and methods for new product development", European Journal of Marketing, Vol. 29, no. 10 (forthcoming).

Oppedijk van Veen, W.M., (1987), "Consumentenonderzoek binnen de faculteit van het industrieel ontwerpen", Delftse Universitaire Pers.

Sanchez, R., en D. Sudharshan, (1993), "Real-time market research: learning by doing in the development of new products", Working paper University of Illinois, Department of Business Administration, Champaign.

Schelker, T., (1976), "Problem/osungsmethoden im ProduktInnovationsprozess", dissertation, Verlag Paul Haupt Bern.

Urban, G.L. en J.R. Hauser, (1993), "Design and marketing of new products", Prentice-Hall, Englewood Cliffs, New Jersey, 2de druk.

Verhage, B., Ph. Waalewijn en A.J. van Weele, (1981), “New product development in Dutch companies: the idea generation stage", European Journal of Marketing, Vol. 15, No. 5, pp. 73-85.

Wittink, D.R. en P. Cattin, "Commercial Use of Conjoint Analysis: An Update", Journal of Marketing, Volume 53 (July) pp. 91-96.

Workman, J.P. Jr., (1993), "Marketing's limited role in new product development in one computer systems firm ", Journal of Marketing Research, november, Volume 30, pp. 405-421.

\section{NOOT}

1 De auteurs bedanken Jan ten Bosch van de NIMA industriële marketing groepering voor het organiseren van de focusgroep. Verder bedanken zij Brenda van Leeuwen, en de referenten en redacteur van het $M A B$ voor hun waardevolle opmerkingen ter verbetering van het oorspronkelijke manuscript.

\section{Bijlage: Omschrijving van de onderzochte modellen en methoden}

Brainstormen: een creatieve groepssessie waarin op systematische wijze ideeën vergaard worden door het wegnemen van beperkingen in het denken.

Concept test: het vragen naar de mening van een aantal afnemers over een bepaald(e) innovatie/produktconcept, die is uitgewerkt op papier of in een simpele 'mock up'.

Conjunct meten: het komen tot een optimale combinatie van attributen van een produkt vanuit afnemersoogpunt, door het meten van de waardering van respondenten voor alternatieve denkbeeldige produkten met uiteenlopende produkteigenschappen (scores op attributen).

Delphi-methode: een schriftelijk onderzoek met meer rondes, waarbij onafhankelijk van elkaar de mening van diverse deskundigen wordt gevraagd. Doordat men na elke ronde feedback krijgt over elkaars mening komt men tot een visie waarover consensus bestaat.

Focusgroep/groepsdiscussie: het achterhalen van informatie over onderliggende behoeften, motieven en gevoelens van bijvoorbeeld afnemers door het organiseren van groepsessies. De discussieleider brengt een aantal onderwerpen ter sprake, waarop men gevraagd wordt te reageren.

In-home-use-test: een aantal respondenten krijgt het produkt mee 'naar huis' om uit te proberen voor een bepaalde periode. Daarna worden eventuele problemen ten aanzien van het produkt, die men heeft ervaren, besproken.

Limited-roll-out: het beperkt introduceren van een nieuw produkt met als doel de markt geleidelijk uit te breiden. Door de geleidelijke introductie kan de marketingstrategie nog aangepast worden en wordt er minder risico gelopen.

Morfologische analyse: het vinden van alle theoretisch denkbare oplossingen voor een probleem, door dit probleem op te splitsen in deelproblemen. Voor elk deelprobleem apart worden verschillende oplossingen gezocht. Deze deeloplossingen worden op verschillende manieren weer 
aan elkaar gekoppeld, zodat oplossingen voor het gehele probleem worden verkregen. Op deze wijze worden oplossingen verkregen waar men anders nooit opgekomen was.

Synectics: ideeën worden voor een probleem gegenereerd in een groepssessie. Het probleem wordt echter zo breed gedefinieerd, dat men het werkelijke probleem niet meer herkent. Dit gebeurt bijvoorbeeld door het geven van een analogie voor het probleem. Oplossingen voor de analogie worden vertaald naar het werkelijke probleem.
Produkt-levenscyclus: weergave in de tijd van de omzet/verkopen van een produkt, resulterend in een S-vormige curve. Het kan worden gebruikt voor het vaststellen van de fase van de levenscyclus waarin een markt verkeert en helpen conclusies te trekken tot de noodzaak een bestaand produkt aan te passen of te gaan zoeken naar nieuwe produkten.

Quality Function Development: een methode die het projectteam ondersteunt bij het identificeren en het eenduidig interpreteren van de wensen van de afnemer, bij het stellen van prioriteiten bij produktattributen en bij het vertalen van produktattributen in technische specificaties. 